\title{
Ambidextrous Learning and Survival of Early International Firms-The Role of Social Media Usage
}

\author{
Emmanuel Kusi Appiah \\ School of Marketing and Communication, International Business, University of Vaasa \\ emmanuel.kusi.appiah@uwasa.fi
}

\begin{abstract}
Prior studies show the importance of social media in facilitating both exploitative learning and exploratory learning. The central concern is how the usage of social media influences the blend of both exploitative learning and exploratory learning known as ambidextrous learning - and the survival of early internationalizing firms. The theoretical discussion in this paper centres on international entrepreneurship, social media usage, and ambidexterity literature. We developed a conceptual model that explains the underlying mechanisms through which social media drives ambidextrous learning and survival. Collectively, these discussions are important to the advancement of knowledge on capability and survival studies in international entrepreneurship.
\end{abstract}

\section{Introduction}

Early internationalizing firms are business entities that make an early leap into foreign markets to seek significant competitive advantage from the use of resources and the sale of output in multiple countries [36]. Such firms are known as international new ventures (INVs). The turbulent nature of the international business environment demands INVs to constantly improve their dynamic capabilities, which can be achieved by learning [44]. Learning is the process of transferring and integrating information to product knowledge. Without learning, firms will be locked-out from current market trends and technologies. According to Autio, Sapienza, and Almeida [10], early internationalizing firms tend to have a learning advantage flowing from their newness that enables them to explore and learn new things derived from the foreign market. They also tend to have a residue of an individual or group international experience which forms the basis of exploitative learning. Digital technologies also offer novel ways for early internationalizing firms to transact business operations, register their global presence, and to develop and manage knowledge [68].

Digital technologies come in different forms. Among them is social media (SM). The low-cost and accessibility of the internet has made the usage of SM platforms, such as Facebook, Twitter, and LinkedIn appealing to early international firms [31]. At both the entrepreneur's level (e.g. [45]) and the organizational level (e.g. [67]), SM is recognized as an important digital tool that influences early internationalization process. International entrepreneurs can use SM to increase their knowledge of customers and convert it into products and services [45]. Besides customers, Sigfusson and Chetty [62] show that international entrepreneurs overcome the liability of outsidership by employing LinkedIn to connect with potential partners to explore and exploit opportunities to be insiders in the relevant network in foreign markets. SM also provides young entrepreneurial firms with distinct ways to build their brands without expensive marketing campaigns, register their global presence, and to forge international business strategies [68].

Prior studies show the importance of SM in the facilitation of knowledge development and organizational learning in firms [61]. For example, Tran, Yonatany and Mahnke [67] found that Facebook's success depended on its ability to use virtual learning tools and supporting systems to acquire, articulate and integrate extramural knowledge from geographically dispersed communities of users to accelerate its rapid internationalization in cyberspace. Despite the prominence of SM usage among early internationalizing firms, there are limited numbers of studies exploring the influence of SM usage on ambidextrous learning and market entry survival. Prior studies on SM and learning centre on causal relationships between SM knowledge management processes and organizational learning (e.g. [58]). Studies on the implications of ambidextrous learning have shown that it has a positive influence on firm performance [28]. Whereas prior work on ambidextrous learning has focused on performance 
implications, the implications for survival among early internationalizing firms is under-researched. The existing studies on survival outcomes of ambidexterity are not centred on organizational learning (e.g. [5]; [55]). These are gaps, we intend to bridge.

This paper identifies aspects of ambidextrous learning and foreign market entry survival that can benefit from the use of SM. To address the research gaps identified above, the focal research question here is: what is the role of SM usage in driving ambidextrous learning and survival following foreign market entry? The theoretical discussions of this paper rely on the international entrepreneurship (IE), information systems (IS), and ambidexterity literature. We use an organizational learning theoretical framework (i.e. exploratory learning and exploitative learning) to conceptualize and explore ambidexterity e.g. [12]. Based on the framework, we develop propositions and provide a conceptual explanation of the underlying mechanisms by which the phenomenon of SM drives ambidextrous learning and survival. Collectively, these discussions advance knowledge within the realm of IE and IS.

The paper makes the following contributions. First, it contributes to capability and survival studies in IE. It does so by showing the interdependencies between SM usage, and the development of ambidextrous learning and survival. Second, as noted by Crossan, Maurer and White [17]: A theory of organizational learning is more about a wellgrounded trunk than it is about adding to the complexity of branches and leaves (p. 454). However, they emphasised that adding more branches and leaves creates the need for an even stronger and sustainable trunk and base to support them, therefore, we contribute to organizational learning theory by strengthening that "trunk". We do this by deepening our understanding of ambidextrous learning within the context of INVs. Third, we contribute to IS literature on SM usage by responding to research calls on how technological context affect the internationalization process of firms [16]; [69].

\section{Theoretical Background}

\subsection{Learning in International Business}

International business is distinguishable from domestic business in being a form of business operations that transcends national borders. It involves "active involvement in establishing a greenfield site abroad, a manufacturing facility in another country, a sales or service centre abroad, cross-border merger or acquisition, or establishment of a cross-border joint venture or strategic alliance" [4], p. 494. All those activities involve an element of learning. Fletcher and Prashantham [23] state, "internationalization is a learning-intensive process" (p. 475). Context sensitivity is important in this process, as differences in cultural context can influence how the firm learns [71]. Scholars (e.g. Zahra, Zheng and $\mathrm{Yu}$ [71]) argue that unlike culturally dissimilar markets, culturally similar markets limits opportunities for organizational learning because knowledge flows from newly entered markets are similar to previous entered markets, adding only incrementally knowledge stocks. The critical learning period in the cycle of a firm during internationalization is in the early and growing stages [4]. This assertion is particularly true of INVs and learning is seen as a capability that drives the early internationalization of that type of firm [23]. The means of learning available to INVs are diverse and might involve learning by using, in relation to the use of products, machinery and inputs; learning from new technological developments; learning from inter-industry spillovers (imitating competitors); learning by interacting; and learning by searching [44] the external environment and the firm's internal milieu [23]. Other forms include congenital learning derived from the experience of the founding members of the firm, and grafting (learning from the expertise of people newly recruited into the firm) [23].

The multiple ways of learning and forms of associated content have impelled organizational theorists to categorize the firm learning process into two main processes: exploratory learning and exploitative learning [46]. Exploratory learning is defined as market-based learning focused on the search for the unknown [40] and new opportunities through the acquisition of knowledge that is distinct from existing organizational expertise [14]. It is the dynamic sensing capability of firms to experiment and identify potential market patterns. In contrast, exploitative learning is defined as the firm's capability "based on routines that allow firms to refine, extend, and leverage existing competencies or to create new ones by incorporating acquired and transformed knowledge into its operations" [73], p. 190). Exploitative learning is thus an internal directed form of learning aimed at adapting the firm to its environment [14] by applying existing knowledge [46]. According to organizational theorists, concurrent or sequential usage of both learning approaches is termed ambidextrous learning [74; 22]. 


\subsection{Ambidextrous Learning}

The international business environment is a turbulent market characterized by inherent uncertainties and dynamism flowing from issues such as technological change, market instability, changing competitive landscapes, unfamiliar consumer preferences, culture differentials, and others. Some of these issues have a direct influence on the competitive situation of the firm while the influence of others is indirect [41] but as a group, they complicate the effective internationalization of firms, and particularly of small firms. The complexity involved justifies firms employing both exploratory and exploitative learning to advance the acquisition of knowledge [23].

Exploratory learning enables INVs to discover threats and opportunities within their environments. Unlike opportunities, threats are difficult to control. Becoming privy to them enables firms to optimize performance and offset threats by engaging with issues over which they have more control [14]. In contrast, exploitative learning provides an avenue for INVs to maximize scarce resources by utilizing currently available market information within the firm's stock of knowledge [46]. The INV literature informs us that founding entrepreneurs and management teams support early internationalization; however, Fletcher and Prashantham [23] add that the support is augmented by new knowledge obtained from the firm's ongoing activities. Learning from the international experiences of entrepreneurs and management teams is about the exploitation of existing knowledge. In contrast, learning from the firm's ongoing international activities is more exploratory than exploitative. Significantly, this means that both exploratory and exploitative learning complement each other [42], though each has a distinct role and associated performance outcome [29].

The uncertain and dynamic nature of foreign market environments [1] implies that firms must practice exploration and exploitation to survive and amass competitive advantage [51]. According to March [46] both exploratory and exploitative learning approaches depend on market uncertainties. Also, they compete for scarce resources, which can create tensions. March [46], therefore, posits that there should be a way to leverage synergy or an alternative way to manage the tensions inherent in the deployment of the two learning approaches. Effective achievement of synergy and management of tensions is what makes a firm ambidextrous [35]. Studies show that there is no single unique way to achieve ambidexterity. Firms have the option to choose either to focus on differentiation tactics or on integration tactics to increase performance. Karafyllia and Zuchella [35] suggest internationalizing firms use integration tactics to leverage synergy and differentiation tactics to manage tensions. Integration tactics involve a firm concurrently utilizing exploratory and exploitative learning in its knowledge development process [13]. Differentiation tactics, in contrast, involve a firm engaged in a knowledge development process focusing on either exploitation or exploration. That firm can then switch from one to the other to suit its strategy at different times.

\subsection{Early Internationalization and Survival}

Scholars, e.g. [46] note that IE research flows from an interest in early internationalization following McDougall's (1989) empirical study comparing domestic ventures and INVs. Since then early internationalization has become one of the prominent research concepts. According to the concept of early internationalization, entrepreneurs choose to internationalize from inception due to the variety of skills they possess, and their abilities to sense opportunities [10]. Oviatt and McDougall [54] conceptualized early internationalizing firms as INVs. INVs are "business organizations that, from inception, seek to derive significant competitive advantage from the use of resources and the sale of output in multiple countries" ([54], p.49). INVs behave radically differently to traditional firms, whose entry into an international market is gradual and sequential, involving a long period of a learning experience and resource accumulation [32]. Some of the common features linked to INVs are the earliness of their foreign market entry [54], network involvement in the facilitation of rapid internationalization [48]; [16], the speed and outcomes of internationalization processes [10], their learning advantage of newness (LAN) [10], and their entrepreneurial orientation [74]. Scholars have used the terms INVs and born globals interchangeably [5]. For the sake of consistency and theoretical parsimony, in this paper we refer to INVs.

Anecdotal evidence from prior research e.g. [59]; [10] shows how INVs survive foreign market entry. Autio et al. [10] report that in the case of having little or no existing domestic knowledge, INVs can deploy LAN that boosts their chances of survival following their foreign market entry. Nevertheless, Sapienza et al. [59] adopt a capability-based perspective and argue that irrespective of LAN, INVs have resource liabilities that reduce their chances of survival but increase the chances of growth if they survive. 
Sapienza et al. [59] also highlighted the role of the prior experience of founders in influencing the survival of INVs. To our knowledge, among these prior studies, none specifically focuses on either the role of SM or ambidextrous learning. We consider these omissions as sweet spots to capitalize on in this paper.

\subsection{SM Usage}

SM is growing in importance as a strategic tool among firms [56] and is changing interactions between firms and consumers [33]. However, Kaplan and Haenlein [34] argue that the understanding of this concept is to a certain extent limited. Some refer to SM as Web 2.0 e.g. [30] but according to Kaplan and Haenlein [34], there are differences between the concept of SM and Web 2.0 because SM platforms are created using Web 2.0 technologies. Web 2.0 offers a new way for users to modify in a participatory and collaborative fashion content built with Adobe Flash, Really Simple Syndication (RSS: web feed formats used to publish frequently updated content, in a standardized format), Asynchronous JavaScript (AJAX: a technique to retrieve data from web servers asynchronously) [34]. Kaplan and Haenlein [34] describe SM as a group of mobile and web applications that build on the ideological and technological foundations of Web 2.0, and that allow users, such as individuals and communities to create, share, collaborate, discuss, and modify usergenerated content [34]. This definition is one of the most-often cited in academic literature [56]. The availability of the internet has provided leeway for individuals to use SM to communicate across geographic locations without a physical presence [26]. Likewise, at the firm level, prior studies have shown the importance of SM for the development and conducting of international business operations (e.g. [2]). Parveen et al. [56] posited SM usage can be split into three sub-constructs: SM used for marketing, for building customer relations, and for accessing information. Examples of SM are networking sites (e.g. Facebook, Twitter, LinkedIn), content communities (e.g. YouTube), blogs, etc. [34].

\section{Conceptual Model and Propositions}

Figure 1 presents a conceptual model of the influence of SM usage in driving ambidextrous learning and market entry survival among INVs. Owing to the challenges posed by resource scarcity among INVs [72], and the low-cost and accessibility of SM [31], we argue that survival prospects of such firms will be enhanced if they employ SM. Further, relying on SM, the firm can concurrently employ exploratory and exploitative learning in its knowledge development process or switch from either exploitation or exploration to suit its strategy at different times [13]. Lastly, INVs are known to contend with environmental uncertainty in global markets, and according to March [46], exploratory and exploitative learning also depends on environmental uncertainty. We, therefore, consider environmental uncertainty to play a moderating role between the probable influence of ambidextrous learning on foreign market entry survival. In sum, the conceptual model establishes a relationship among organizational contextual characteristics, SM usage, ambidextrous learning, and survival. We also incorporate differences in cultural context (i.e. a culturally similar market versus a culturally dissimilar market).

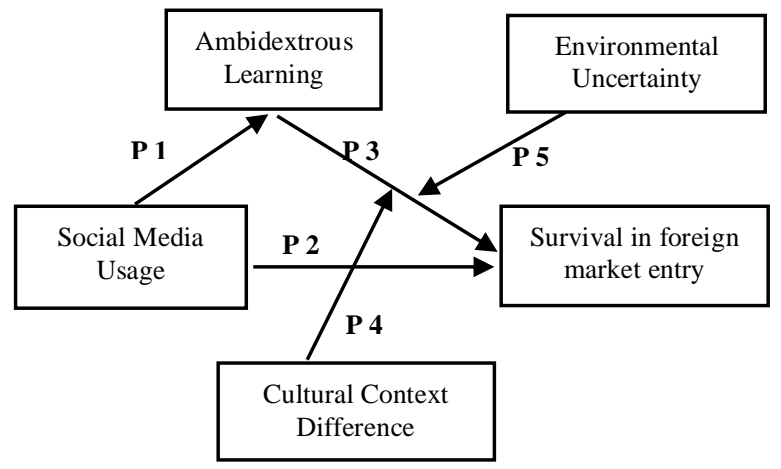

Figure 1. Conceptual Model

\subsection{SM usage and Ambidextrous Learning}

SM facilitates cross-boundary communication and conversation, preserves institutional memory, harnesses distributed knowledge, and reveals emerging opportunities [47]. It also provides new knowledge that supports exploratory learning and facilitates the conversion of new knowledge into practical knowledge through content creation and sharing. Unlike traditional CRM, where information is delivered from the firm to the customer with the sole aim of creating a one-to-one relationship [66], SM provides a network of many-to-many relationships whereby the firm interacts with customers and other stakeholders by creating and sharing content [37], which by adding online followers extends the firm's knowledge repertoire.

Firms also use SM as a channel to access information on customers and competitors; for instance, using a simple hashtag on Twitter, a firm can explore and know all that has been said or written 
on followers. There are also SM search tools that facilitate the exploratory learning of firms such as Twitter Advanced Search, Bing Social Search, etc. Within the firm, SM platforms such as microblogs and SharePoint serve as a facility for the preservation of organizational memory that supports exploratory and exploitative learning. On these platforms, the organization's members can interact socially to share knowledge and apply it effectively to the firm's business activities. If, for example, individual members or functional units have to deal with complaints from customers, they might search through online conversations to discover if any unit or individual has encountered similar challenges before. If there is no precedent, the unit can post the challenge on the platform for individuals and other units to share their existing expertise on how to overcome it.

Lastly, in using SM for marketing, firms usually create online communities where users and potential customers congregate and interact around their products and services. The more the interaction develops, the more enthusiastic users or consumers will become about sharing the firm's product and services on their SM timelines. The online communities make it possible for users and customers to submit reviews, recommendations, and ratings of the firm's product and services [26]. They also create fan pages where customers and users can comment, like, or dislike the firm's services or products. On these pages, firms post product or service-related videos, messages, quizzes, information, and other materials. The creation of online communities and fan pages opens opportunities for firms to discover information about their potential customers, their tastes, their explicit and implied needs from their conversations on the firms' fan pages.

In summary, using SM for marketing, building customer relationships, and to access information provides an array of data from the market that can be used to explore and exploit knowledge digitally [12]. Hence, we make the following proposition.

Proposition 1: SM usage for marketing, building customer relations and information accessibility positively influences ambidextrous learning.

\subsection{SM and Market Entry Survival}

The survival of INVs in foreign markets depends on how they overcome the liabilities of newness, and foreignness [74; 59]. A liability of newness exists because early internationalizing firms usually lack specific sets of resources and capacities to compete in foreign markets [72], which can spur failure.
Proponents posit that due to liability of newness the risk of INV dying is at the highest during its inception and decreases, as it becomes older [72]. Studies have shown how digital technology can support new ventures in overcoming the liability of newness. For example, Morse, Fowler and Lawrence [49] developed a theoretical framework to address how the adoption of virtual embeddedness by new ventures affects the likelihood of their survival by mitigating the liabilities of newness rising from the need to create and manage new roles and systems, lack of social capital, lack of economic capital, and lack of relational trust. The authors use the term virtual embeddedness to refer to the establishment of inter-organizational connections through the use of internet-based technologies [24]. Arenius et al. [6] also found that the internet can offer a way to reduce the effects of the liability of foreignness and resource scarcity. The liability of foreignness is often associated with the costs of trading abroad including but not limited to travel and transportation costs, coordination costs, and those flowing from efforts to establish legitimacy.

Similarly, the use of SM can ease the difficulties resulting from liabilities of newness, and foreignness, that hampers the survival of firms. Firstly, due to the low-cost and accessibility of the internet, the usage of SM for marketing (e.g. via Twitter, Instagram, and Facebook) in the foreign market enable INVs to overcome their paucity of resources by reducing transaction costs in marketing activities associated with liabilities of foreignness. For example, many internationalizing firms have set up shops on Facebook, Twitter, Instagram and other SM networks in pursuit of new customers as a means to overcome their paucity of resources. Uber began as an early international firm and has used SM to grow very fast. It offered incentives to riders in exchange for a SM share. The SM channels are more cost-effective than traditional marketing, advertisements, and promotions conveyed through radio, TV, newspapers, and the like.

Secondly, having the difficulty in achieving legitimacy (i.e. liability of foreignness), the usage of SM to facilitate technology-enabled customer relationship management can create an opportunity to pluralize ongoing discussions about firms. Unlike in the past where organizational legitimacy was assessed by news media, surveys, and governmental agencies [21], presently, SM enables the internationalizing firm to include the voices of customers, users, and the public. The individual tweets, Facebook posts, LinkedIn posts, and blogs judgements about the firm mitigate perceived risks and enhance the legitimacy of the firm in a foreign 
market [7]; [2]. This effect was confirmed in a study conducted by Arnone et al. [7] on the role of social networking sites in the internationalization of small businesses.

Thirdly, the use of SM search tools (e.g., Buzzsumo, Tagboard, and AgoraPulse) to improve access to information can provide INVs with more information on customers, competitors, existing, and new geographic markets than would be available without using such tools. Such usage reduces the difficulty in acquiring foreign market knowledge arising from the liability of newness as exacerbated by the liability of foreignness that has the possibility of hampering the survival of the firm. Based on the foregoing discussions, a direct relationship between SM usage and market entry survival is proposed.

Proposition 2: SM usage for marketing, building customer relations, and information accessibility positively enhance the survival of INVs.

\subsection{Ambidextrous Learning and INV Survival}

Exploratory learning improves opportunities for the firm to amass new knowledge through the process of discovery. Exploitative learning also promotes the emergence of new knowledge through the combination and recombination of existing knowledge [9]. It often leads to early success [25]; however, during the internationalization process, INVs need both exploratory and exploitative learning because new ventures that depend solely on exploitative learning lack an understanding of market conditions that differ from their current environment [46]. As a result, INVs find it difficult to adapt to emerging changes within the foreign market and tend to suffer from a competency trap [15], also known as organizational inertia [42] or a success trap [40]. A firm can fall into a competency trap when its core competence becomes a core rigidity, which causes the firm to focus on existing competencies and routines and ignore new forms of knowledge in the mistaken belief that existing competencies and routines will continue to be effective in the future. Competency trap can also affect new product development, although exploitative learning may enhance survival and performance, beyond a certain point the level of survival-related performance diminishes due to knowledge ossification [9]. In contrast, new ventures that prioritize exploration suffer from internal inefficiencies and information myopia [12] known as the failure trap [40]. A failure trap occurs when the firm is clustered with diversity body of new knowledge but does not exploit prior learning and experience [46]. Depending solely on exploratory learning nullifies the short-term commercial benefits that new ventures can achieve [40]. In addition, Autio et al. [10] studied LAN and showed that in the early stages of INVs' internationalization, they have an exploratory learning ability in the form of LAN that supports their survival; however, as INVs age they develop internal rigidities that render LAN obsolete. We, therefore, argue that it is appropriate for INVs to adopt ambidextrous learning processes. Ambidextrous learning paves the way for firms to integrate exogenous knowledge with existing knowledge, prevents organizational inertia and information myopia, and creates new capabilities that enhance the achievement of commercial benefits and sustainable competitive advantage [38]. Based on the foregoing discussion, we propose that:

Proposition 3: Ambidextrous learning positively influences the survival prospects of INVs.

\subsection{Cultural Context Difference}

Achieving ambidexterity in learning is about the balance of how high or low levels of exploratory learning are applied and how low or high levels of exploitative learning are used either simultaneously or sequentially. The path dependence perspective shows that when INVs pursuing a rapid internationalization process enter a culturally similar foreign market they have entered before, they tend to invoke more exploitative learning than exploratory learning. That choice stems from the similar knowledge flows, culture, and business climate. They benefit from replicating the knowledge and experience of the entrepreneur and the knowledge acquired from one foreign market in other similar markets and settings [70]. Fletcher and Prashantham [23] state the effectiveness of exploitative learning in the internationalization process is augmented by new knowledge obtained from the firm's ongoing activities [23]. In terms of balance, because of resource scarcity, the greater focus is on differentiation tactics as the firm shifts from exploitative learning to exploratory learning as required to align activities and strategies with environmental situations [53]. However, when a firm enters a culturally dissimilar market, it must address a high level of psychic distance which prompts it to embark on exploratory learning [71]. Characterized by the LAN, the internationalizing firm has to do more exploratory learning than exploitative learning to understand the market dynamics, structures, and institutions of the particular target market. Under the conditions of absence or few existing organizational routines to unlearn, the knowledge acquired from exploratory learning is maximized in domains close 
to the domain of existing knowledge [52]. For this reason, in terms of balance, INVs focus more on differentiation tactics, which involves a shift from exploratory learning to exploitative learning when required to align activities and strategies with environmental situations [53]. In conclusion, the balance between exploratory and exploitative learning due to cultural contextual differences creates a knowledge intensity that enhances international growth and sustainable competitive advantage [38]. We propose that:

Proposition 4: The relationship between ambidextrous learning and market entry survival is moderated by differences in the cultural context that the INV enters.

\subsection{Environmental Uncertainty}

The resource dependence literature recognizes that the external environment in which firms operate potentially influences their behaviours [3]. There are a multitude of ways to describe the external environment of firms; for example, Duncan [20] describes the environment based on simple/complexity and static/dynamism dimensions, while, adopting a different perspective, Ansoff [8] describes the environment as a function of changeability and predictability with five different turbulence levels - namely, the repetitive, expanding, changing, discontinuous and surprising environments. In line with Dess and Beard [19], we describe the environment based on uncertainty through the dimensions of complexity, dynamism, and munificence. Complexity refers to the multiple external factors and challenges that the firm encounters. It includes heterogeneity in customer demands, cultural dissimilarity, diversity in operational processes, and competitors [64]. Dynamism defines the degree of change inherent in the factors emanating from environmental complexity. Finally, munificence defines the ability of the environment to support the growth of the firm [3].

The degree of uncertainty determines the benefits that a firm might derive from learning [42]. Though INVs have LAN to support them in exploring and acquiring new knowledge in environments characterized by a high degree of cultural dissimilarity [71], and the experiences of founders to depend upon to cement knowledge exploitation; they do not have adequate resources to meet the necessary demands of the environment, as established by research on the liability of smallness [60]. Pehrsson et al. [57] discovered that despite the advantages accruing from LAN, developing dynamic capabilities in the early stages of internationalization is resource sapping and causes firms that do not have existing resources or connections fail to build new capabilities to amass competitive advantage and performance. Inadequate resources can also adversely affect the strategies, operations, and learning processes of INVs. Building on the premise of the liability of smallness (i.e. resource scarcity) [72], we argue that environments marked by high complexity and dynamism will have an adverse effect on the relationship between ambidextrous learning and survival. The reason is that in such environments, firms' survival and growth depend on their resources [27], although some scholars argue that slack resources can impose constraints on a firm [18]; [50]. In addition, according to the resource-based view, sustained competitive advantage is more a function of firm resources than of industry structure [65]. In contrast, when the INV enters an environment of munificence, although it lacks resources, the environment provides the opportunity for it to create resources through the accumulation of revenues that can support survival and growth [3]; [11]. Although developing dynamic capabilities in the early stages of internationalization is resource sapping [57], a munificent environment can provide INVs with the confidence and energy to build new capabilities and develop a long-term strategy to amass competitive advantage [11]. The foregoing arguments prompt the following proposition:

Proposition 5: The relationship between ambidextrous learning and the survival of INVs is moderated by environmental uncertainty.

\section{Discussions and Implications}

This paper extends the current debate surrounding ambidexterity. The topic of ambidexterity has attracted attention across different academic disciplines [43]; however, the "understanding of its determinants and consequence has remained rather vague" [39], p. 1109. Among the related studies, few centre on international new ventures (INVs). Relating the concept of ambidexterity to early internationalization and organizational learning literature, this paper extends our conceptual understanding of the determinants and consequences of ambidexterity. We propose SM usage is a determinant of ambidextrous learning with a consequent influence on survival following new market entry. As a point of explanation, we show the interdependencies between SM usage and the development of ambidextrous learning and survival by developing a conceptual model and propositions. Our conceptual model clarifies the normative 
implications of ambidextrous learning in the context of SM usage. To advance theoretical development, we incorporated key contingencies from internationalization process literature: environmental uncertainty and differences in cultural context. In summary, the discussions in the present paper will have important implications for both academics and practitioners.

\subsection{Theoretical and Practical Implications}

First, the paper contributes to a capability-based view of the effects of early internationalization on survival studies in IE. Researchers suggest that early internationalizing firms face a deficiency of the resources and capabilities required to compete in foreign markets [57]. In addition, they encounter a liability of foreignness that challenges their survival and growth [72]. Despite these liabilities, studies also show that they have a LAN to foster exploratory learning and can also call on a residue of individual or group international experience which forms the basis of exploitative learning [10]. These characteristics provide an interesting context in which to study ambidextrous learning. Building on ambidexterity literature, we provide insights to help understand how digital capabilities in terms of SM usage influence the survival following foreign market entry.

Second, we contribute to organizational learning theory by extending the understanding of ambidextrous learning and its implications for organizational survival within the context of early internationalizing firms. We have strengthened the "trunk" of organizational learning theory by examining it peripherally and highlighting its importance in early internationalization.

Third, we contribute to IS literature on digitalization by focusing on SM usage in the context of ambidextrous learning and its implications for firm survival. Studies on SM usage, although not yet numerous, have provided evidence of the implications of SM for the activities of internationalizing firms (e.g. [67]; [45]. Those last referenced studies show that SM usage enables international knowledge acquisition to support rapid internationalization. Our perspective extends such studies by generating discussions on its impacts on ambidextrous learning and survival.

Rather than recommending a course of action, this paper provides a comprehensive view of SM in enterprise management. That said, international entrepreneurs that see the importance of SM usage in their operations may wish to consider the implications of the derived propositions. Empirical confirmation of these propositions calls for international entrepreneurs to pay close attention to the usage of SM in their organizational learning activities and foreign market entry survival. This paper also provides insights to help international entrepreneurs understand the need to apply ambidexterity in their organizational learning process when operating in foreign markets. Scholars warn that applying ambidexterity is not straightforward (e.g. [63]). Entrepreneurs and firms have to understand the influential factors and mechanisms that support ambidexterity. This paper will, therefore, serve as an invaluable source of information for their decision-making processes.

\subsection{Limitations and Future Research Agenda}

The major limitation of the present paper lies in its conceptual nature, in the sense that there are no data or empirical justifications to buttress the discussions. However, several promising avenues for future theoretical advancement are apparent. We suggest that further studies empirically test our conceptual model and propositions described in Figure 1 from both cross-sectional and longitudinal perspectives. Such a course will advance our knowledge of capability-based view studies in IE, and SM in enterprise research in the field of IS.

\section{References}

[1] Achrol, S. R. (1991). Evolution of the Marketing Organization. Journal of Marketing, 55, 77-93.

[2] Alarcón-del-Amo, M., Rialp-Criado, A. and RialpCriado, J. (2018). Examining the impact of managerial involvement with social media on exporting firm performance. International Business Review, 27(2), 355366.

[3] Aldrich, H. and Auster, E. (1986). Even dwarfs started small: Liabilities of age and size and their strategic implications. Research in Organizational Behavior, 8, 165-98.

[4] Anderson, V., Graham, S. and Lawrence, P. (1998). Learning to internationalize. Journal of Management Development, 17(7), 492-502.

[5] Andersson S., Evers N. and Kuivalainen O. (2014). International new ventures: rapid internationalization across different industry contexts. European Business Review, 26(5), 390 - 405.

[6] Arenius, P., Sasi, V. and Gabrielsson, M. (2005). Rapid internationalization enabled by the Internet: The case of a knowledge intensive company. Journal of International Entrepreneurship, 3, 279-290.

[7] Arnone, L. and Deprince, E. (2016). Small Firms Internationalization: Reducing the Psychic Distance Using Social Networks Global. Journal of Business Research 10(1), 55-63. 
[8] Ansoff, H. I. (1979). Strategic Management. Macmillan.

[9] Atuahene-Gima, K., and Murray J. Y. (2007). Exploratory and exploitative learning in new product development: A social capital perspective on new technology ventures in China. Journal of International Marketing 15(2), 1-29.

[10] Autio, E., Sapienza, H. J. and Almeida, J. G. (2000). Effects of age at entry, knowledge intensity, and imitability on international growth. Academy of Management Journal, 43(5), 909-924.

[11] Barney J. (1991). Firm Resources and Sustained Competitive Advantage. Journal of Management 17(1), 99120.

[12] Benitez, J., Castillo, A., Llorens, J., and Braojos, J. (2018). IT-enabled knowledge ambidexterity and innovation performance in small US firms: the moderator role of social media capability. Information Management, 55(1), 131-143.

[13] Birkinshaw, J. and Gibson, C.B. (2004). Building ambidexterity into an organization. MIT Sloan Management Review, 45(4), 47-55.

[14] Chattopadhyay, P., Glick, W. H. and Huber, G. P. (2001). Organizational Actions in Response to Threats and Opportunities. Academy of Management Journal, 44(5), 937-955.

[15] Cohen, W. and Levinthal, D. (1990). Absorptive Capacity: A New Perspective on Learning and Innovation. Administrative Science Quarterly, 28, 223-244.

[16] Coviello, N. E. and Munro, H. J. (1995). Growing the entrepreneurial firm networking for international market development. European Journal of Marketing, 29(7), 49-61. [17] Crossan, M. M., Maurer, C. C. and White, R. E. (2011). Reflections on the 2009 AMR decade award: Do we have a theory of organizational learning? Academy of Management Review, 36, 446-460.

[18] Dasi, A., Iborra, M. and Safón, V. (2015). Beyond path dependence: Explorative orientation, slack resources, and managerial intentionality to internationalize in SMEs. International Business Review, 24(1), 77-88.

[19] Dess, G. G. and Beard, D. W. (1984). Dimensions of Organizational Task Environments. Administrative Science Quarterly, 29(1), 52-73.

[20] Duncan, R. (1972). Characteristics of organizational environments and perceived uncertainty. Administrative Science Quarterly, 2, 409-443.

[21] Etter M, Colleoni E, Illia L, Meggiorin K, D’Eugenio A. 2018. Measuring Organizational Legitimacy in Social Media: Assessing Citizens' Judgments With Sentiment Analysis. Business \& Society, 57(1):60-97.

[22] Evers, N. and Andersson S. (In Press). Predictive and effectual decision-making in high-tech international new ventures- A matter of sequential ambidexterity. International Business Review.

[23] Fletcher, M. and Prashantham, S. (2011). Knowledge assimilation processes of rapidly internationalizing firms: Longitudinal case studies of Scottish SMEs. Journal of Small Business and Enterprise Dev't, 18(3), 475-501.

[24] Fowler, S. F., Lawrence, T. B., and Morse, E. A. (2004). Virtually embedded ties. Journal of Management, 30, 647-666.
[25] Gupta, A. K., Smith, K. G. and Shalley, C. E. (2006). The interplay between exploration and exploitation. Academy of Management Journal, 49, 693-708.

[26] Hajli, M. N. (2014) A Study of the Impact of Social Media on Consumers. International Journal of Market Research, 56, 387-404.

[27] Helfat, C. E., and Peteraf, M. A. (2003). The dynamic resource-based view: Capability lifecycles. Strategic Management Journal, 24(10), 997-1010.

[28] Hsu, C., Lien, Y. and Chen, H. (2013). International ambidexterity and firm performance in small emerging economies. Journal of World Business, 48 (1), 58-67.

[29] Isobe, T., Makino, S. and Montgomery, D. B. (2004). Exploitation, Exploration, and Firm Performance: The Case of Small Manufacturing Firms in Japan. Research Collection, Lee Kong Chian School of Business.

[30] Jagongo, A. and Kinyua, C. 2013. The Social Media and Entrepreneurship Growth: A New Business Communication Paradigm among SMEs in Nairobi. International Journal of Humanities and Social Science 3(10), 213-227.

[31] Jean, R-J. B., Kim, D. and Cavusgil, E. (2020). Antecedents and outcomes of digital platform risk for international new ventures' internationalization. Journal of World Business 55:101021.

[32] Johanson, J. and Vahlne J. E. (1977). The Internationalization Process of the Firm-A Model of Knowledge Development and Increasing Foreign Market Commitments. Journal of International Business Studies, 8(1), 23-32.

[33] Kao, T. Y., Yang, M. H., Wu, J. T. B. and Cheng, Y. Y. (2016). Co-creating value with consumers through social media. Journal of Services Marketing, 30(2), 141151.

[34] Kaplan, A. M. and Haenlein, M. (2010). Users of the world, unite! The challenges and opportunities of social media. Business Horizon, 53, 59-68.

[35] Karafyllia, M. and Zucchella, A. (2017). Synergies and tensions between and within domestic and international market activities of firms. International Business Review, 26(5), 942-958.

[36] Knight, G., Cavusgil, S. (2004). Innovation, organizational capabilities, and the born-global firm. Journal of International Business Studies, 35, 124-141.

[37] Lagrosen, O. S. and Grundén, K. 2014. Social media marketing in the wellness industry. The TQM Journal, 26(3), 253-260.

[38] Li, C., Lin, C. and Chu, C. (2008), "The nature of market orientation and the ambidexterity of innovations", Management Decision, Vol. 46 No. 7, pp. 1002-1026.

[39] Lee, C. Y. and Huang, Y. C. (2012). Knowledge stock, ambidextrous learning, and firm performance. Management Decision, 50(6), 1096-1116.

[40] Levinthal, D.A. and March, J.G. (1993). The Myopia of Learning. Strategic Management Journal 14, 95-112.

[41] Liao, J., Welsch, H. and Stoica, M. (2003). Organizational Absorptive Capacity and Responsiveness: An Empirical Investigation of Growth-Oriented SMEs. Entrepreneurship Theory and Practice, 28(1), 63-86.

[42] Lichtenthaler, U. (2009). Absorptive Capacity, Environmental Turbulence, and the Complementarity of 
Organizational Learning Processes. The Academy of Management Journal, 52(4), 822-846.

[43] Luzon, M. D. M. and Pasola, J. V. (2011). Ambidexterity and total quality management: towards a research agenda", Management Decision, 49(6), 927-947.

[44] Malerba, F. (1992). Learning by Firms and Incremental Technical Change. The Economic Journal, 102(413), 845-859.

[45] Maltby, T. (2012). Using Social Media to Accelerate the Internationalization of Startups from Inception. Technology Innovation Management Review, 22-26.

[46] March, J. G. (1991). Exploration and Exploitation in Organizational Learning. Organization Science, 2: 71-87.

[47] Mardi, M., Arief, M., Furinto, A. and Kumaradjaja, R. 2018. Sustaining Organizational Performance through Organizational Ambidexterity by Adapting Social Technology. Journal of the Knowledge Economy, 9(3), 1049-1066.

[48] McDougall, P. P., Shane, S., and Oviatt, B. M. (1994). Explaining the formation of international new ventures: The limits of theories from international business research. Journal of Business Venturing, 9, 469-487.

[49] Morse, E. A., Fowler, S. W. and Lawrence, T. B. (2007). The Impact of Virtual Embeddedness on New Venture Survival: Overcoming the Liabilities of Newness. Entrepreneurship Theory and Practice, 31(2), 139-159.

[50] Mosakowski E. (2002). Overcoming resource disadvantages in entrepreneurial firms: when less is more. In Strategic Entrepreneurship: Creating a New Mindset, Hitt MA, Ireland RD, Camp SM, Sexton DL (eds). Blackwell: Malden, MA; 106-126.

[51] Mudambi, R. and Swift, T. (2011). Proactive R\&D management and firm growth: A punctuated equilibrium model. Research Policy. 40(3), 429-440.

[52] Nonaka, I. (1994). A Dynamic Theory of Organizational Knowledge Creation. Organization Science, 5(1), 14-37.

[53] O'Reilly, C. A. and Tushman, M. L. (2013). Organizational Ambidexterity: Past, Present, and Future Academy of Management Perspectives, 27(4).

[54] Oviatt B. M. and McDougall P. P. (1994). Toward a theory of international new ventures. Journal of International Business Studies, 25 (1), 45-64.

[55] Parida, V., Lahti, T. and Wincent, J. (2016). Exploration and exploitation and firm performance variability: a study of ambidexterity in entrepreneurial firms. International Entrepreneurship Management Journal, $12,1147-1164$.

[56] Parveen, F. Jaafar, N. I. and Ainin, S. (2016). Social media's impact on organizational performance and entrepreneurial orientation in organizations. Management Decision 54(9), 2208-2234.

[57] Pehrsson, T., Ghannad, N., Pehrsson, A., Abt, T., Chen, S., Erath, F. and Hammarstig, T. (2015). Dynamic capabilities and performance in foreign markets: developments within international new ventures. Journal of International Entrepreneurship, 13(1), 28-48.

[58] Qi, C. and Chau, P. Y. K. (2018) Will enterprise social networking systems promote knowledge management and organizational learning? An empirical study, Journal of
Organizational Computing and Electronic Commerce, 28(1), 31-57.

[59] Sapienza, H. J., Autio, E., George, G., and Zahra, S. A. (2006). A capabilities perspective on the effects of early internationalization on firm survival and growth. Academy of Management Review, 31(4), 914-933.

[60] Sapienza, H. J, Autio, E. and Zahra, S. (2003). Effects of internationalization on young firms' prospects for survival and growth. Academy of Management Proceedings: G1-G7.

[61] Scott, J. E. (2000). Facilitating inter-organizational learning with information technology. Journal of Management Information Systems, 17(2), 81-113.

[62] Sigfusson, T. and Chetty, S. (2013). Building international entrepreneurial virtual networks in cyberspace. Journal of World Business, 48(2), 260-270.

[63] Smith, W. K. and Tushman, M. L. (2005). Managing Strategic Contradictions: A Top Management Model for Managing Innovation. Organization Science, 16(5), 522536.

[64] Simsek, Z. (2009). Organizational ambidexterity: Towards a multilevel understanding. Journal of Management Studies, 46, 597-624.

[65] SubbaNarasimha, P. N. (2001). Strategy in turbulent environments: the role of dynamic competence. Managerial and Decision Economics, 22(4-5), 201-212.

[66] Trainor, K. J. (2012). Relating Social Media Technologies to Performance: A Capabilities-Based Perspective. Journal of Personal Selling \& Sales Management, 32(3), 317-331.

[67] Tran, Y., Yonatany, M. and Mahnke, V. (2016). Crowdsourced translation for rapid internationalization in cyberspace: A learning perspective. International Business Review, 25(2), 484-494.

[68] Tseng, K. M. K. and Johnsen, R. E. (2011). Internationalization and the internet in UK manufacturing SMEs. Journal of Small Business and Enterprise Development, 18(3), 571-593.

[69] Vahlne, J. E. and Johanson, J. (2017). From internationalization to evolution: The Uppsala model at 40 years. Journal of International Business Studies 48(9), 1087-1102.

[70] Vissaka, T., Francioni, B. and Freeman, S. (2020). Foreign market entries, exits and re-entries: The role of knowledge, network relationships and decision-making logic. International Business Review 29, 101592.

[71] Zahra, S.A., Zheng, C. and Yu, J. (2018). Learning advantages of newness: A reconceptualization and contingent framework. Journal of International Entrepreneurship, 16, 12.

[72] Zahra, S. A. (2005). A Theory of International New Ventures: A Decade of Research. Journal of International Business Studies, 36(1), 20-28.

[73] Zahra, S. A. and George, G. (2002). Absorptive capacity: a review, reconceptualization, and extension. Academy of Management Review, 27 (2), 185-203.

[74] Zhou, L., Barnes, B. R. and Lu, Y. (2010). Entrepreneurial proclivity, capability upgrading and performance advantage of newness among international new ventures. Journal of International Business Studies, 41, 882-905. 